\title{
Spring invasion of Heterodera schachtii in sugarbeet; a simulation study
}

\author{
W. VAN DER WERF ${ }^{1}$, R. RABBINGE ${ }^{1}$ and W. HEIJBROEK ${ }^{2}$
}

1 Department of Theoretical Production Ecology, Agricultural University, P.O. Box 430, 6700

AK Wageningen, the Netherlands

${ }^{2}$ Sugar Beet Research Institute, P.O. Box 32, 4600 AA Bergen op Zoom, the Netherlands

Accepted 6 November 1985

\begin{abstract}
A simulation model was developed for the spring invasion of the beet cyst nematode, Heterodera schachtii Schmidt, into sugarbeet roots, according to the state variable approach. This model describes the processes of egghatch, emergence of second stage larvae from cysts, migration to roots and penetration into roots quantitatively, using published data.

In 1983 a field experiment was conducted to test this model. $H$. schachtii cysts were introduced at depths of 6-29 cm in PVC-cylinders, buried in the soil. The rooting depth of sugarbeet seedlings, growing in these cylinders, was limited to $5 \mathrm{~cm}$ by $50 \mu \mathrm{m}$ mesh nylon gauze. Every 10 days the second stage larvae, which had penetrated into the roots of these seedlings were counted. After 50 days, about $40 \%$ of the eggs had hatched. More than $20 \%$ of the emerged larvae penetrated if the cysts had been buried undeeply, and only $4 \%$ if the cysts had been buried at $29 \mathrm{~cm}$ depth.

The model predicted the course of penetration into the root during the first 40 days with reasonable accuracy $\left(\mathrm{r}^{2}=0.79\right)$, but in the 5 th period of 10 days the model made an overestimation of more than $100 \%$. Egghatch after 50 days was correctly simulated. The differences in penetration into the root between the model and the experiment might result from an oversimplified simulation of the penetration success or the neglection of mortality of second stage larvae. Detailed experiments should be done to provide better parameters for these factors.
\end{abstract}

Additional keywords: beet cyst nematode, computer model.

\section{Introduction}

The beet cyst nematode, Heterodera schachtii Schmidt, is one of the most important pests of sugarbeet. Its population dynamics and the damage it inflicts on sugarbeet depend very much on the soil and the season. Simulation models, describing the lifecycle of the nematode together with the growth of the crop, could be used to look for the causes of these differences. As a first step a model of the spring invasion of $H$. schachtii was constructed using published data, and the results of this model were compared with the results of a microscale field experiment.

\section{Construction of the model}

The process of spring invasion can be divided into the subprocesses of egghatch, emergence of larvae from cysts, migration of larvae from cysts to host roots, and 


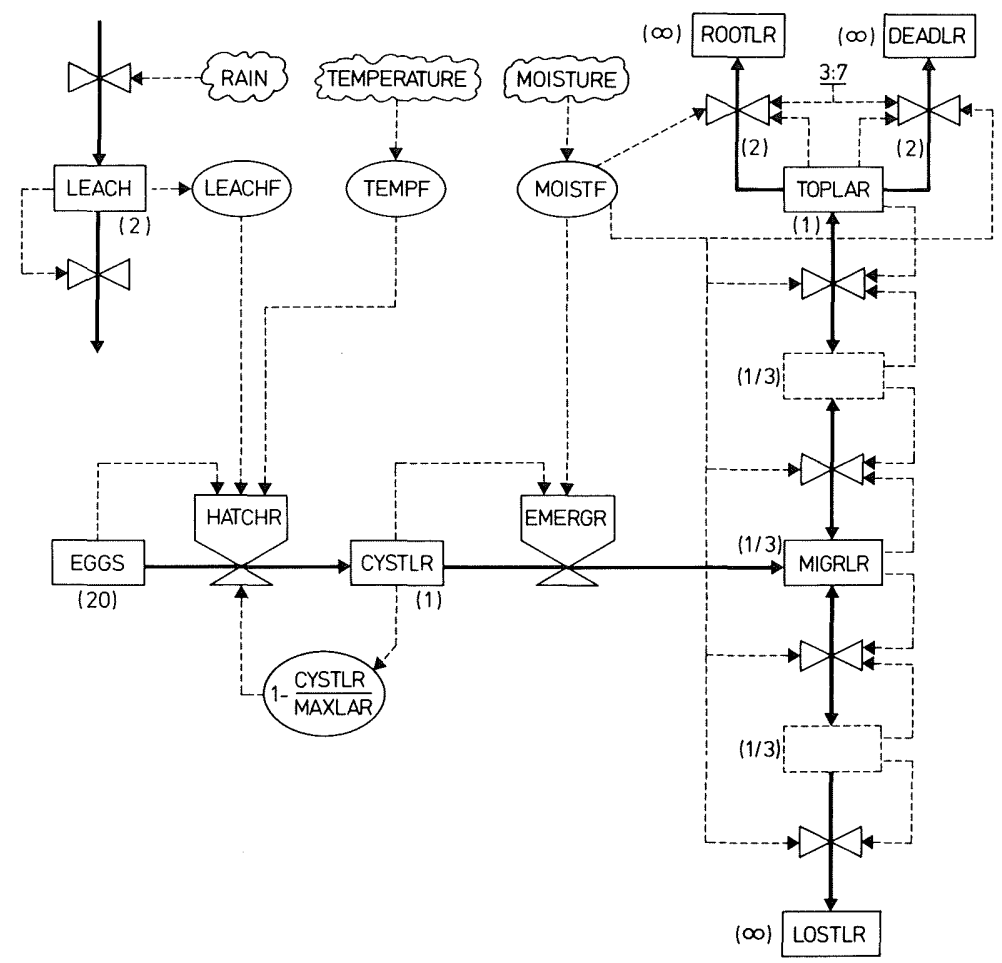

Fig. 1. Relational diagram illustrating the structure of the simulation model of the spring invasion of Heterodera schachtii in sugarbeet. Boxes represent state variables, valves are rates, ovals are auxiliary variables and clouds are the driving environmental variables. Values in brackets represent the minimum average residence time (days) or the inverse of the maximum attainable relative rate of outflow. Solid lines represent the transfer of nematodes or root leachates (LEACH) and broken lines represent the transfer of information. Only two soil layers with migrating larvae are shown (MIGRLR and TOPLAR). The other five layers are represented by the dotted boxes.

penetration into roots. These processes are affected by soil temperature, soil moisture $(\mathrm{pF})$ and root leachates, washed into the soil by rain. The model of the spring invasion is constructed according to the state variable approach (De Wit and Goudriaan, 1978). The state variables distinguished for the stages of the nematode are: unhatched eggs in cysts (EGGS), encysted larvae (CYSTLR), migrating larvae in 7 soil layers of $5 \mathrm{~cm}$ thickness (a.o. MIGRLR and TOPLAR), penetrated larvae (ROOTLR), larvae not able to penetrate (DEADLR), and larvae which have disappeared through the bottom of the cylinder (LOSTLR, Fig. 1).

The rate of transfer of nematodes from one state to the next is proportional to the contents of the source state and to the inverse of the average residence time in the source state or the relative rate of transfer. The relative rate of transfer is determined by the environmental conditions.

Egghatch. For egghatch the relative rate depends also on the presence of hatched lar- 


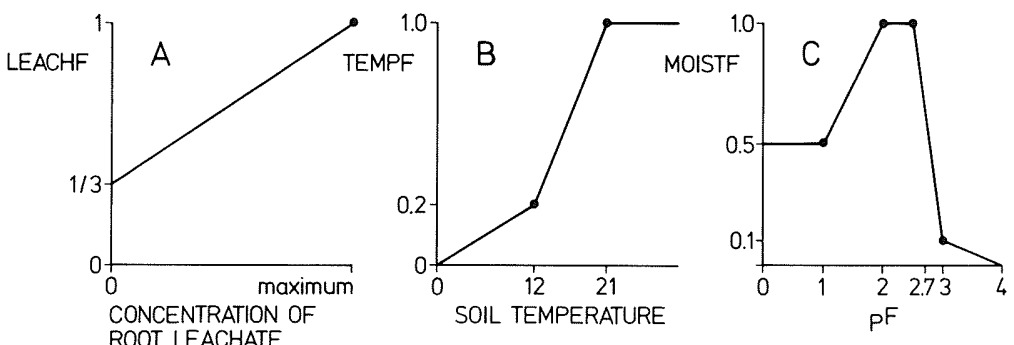

Fig. 2. Multiplication factors which express environmental effects on the rate of spring invasion of Heterodera schachtii. A) The effect of root leachates on the multiplication factor of egghatch (LEACHF). B) The effect of soil temperature on the multiplication factor of egghatch (TEMPF). C) The effect of the $\mathrm{pF}$ of the soil on the multiplication factor of processes where locomotion is necessary (emergence, migration and penetration (MOISTF)).

vae in the cyst (CYSTLR; Wallace, 1959), which compete for oxygen and hence inhibit further egghatch. The rate of egghatch is defined as:

HATCHR $=$ EGGS $*$ LEACHF $*$ TEMPF $*(1-$ CYSTLR/MAXLAR $) * 1 / 20$

LEACHF accounts for the effect of root leachates on egghatch (Maas and Heijbroek, 1982; Fig. 2a) and TEMPF for the effect of temperature (unpublished data; Maas and Heijbroek, 1982; Fig. 2b). The maximum number of larvae in the cyst, MAXLAR, is assumed to be $10 \%$ of the initial cyst contents, and $1 / 20$ day $^{-1}$ is the maximum attainable relative rate of egghatch, which corresponds to a mean duration of egghatch of 20 days. It is assumed that the maximum concentration and full stimulating effect of root leachates is reached in all soil layers after rainfall of more than $10 \mathrm{~mm}$ per day. TShe concentration decreases thereafter with an average decay period of two days, as found by Fenwick (1956) for potato root leachate.

Emergence of larvae from cysts. Emergence of larvae from cysts is controlled by the number of larvae in the cyst and by the $\mathrm{pF}$ of the soil:

\section{EMERGR $=$ CYSTLR $*$ MOISTF}

The relation between MOISTF and the $\mathrm{pF}$ of the soil was derived from Wallace (1955, 1956, 1959; Fig. 2c).

Migration from the cyst to the roots. The migration rates are controlled in essentially the same way as emergence, except that emergence is a one-way movement and migration both up- and downwards. Migration is assumed to be at random because there is no indication for the attraction of $H$. schachtii to roots (e.g. Bergman and van Duuren, 1959). Under favourable conditions $(2<\mathrm{pF}<2.7$, MOISTF $=1)$ migrating second stage larvae have an average residence time per soil layer of $1 / 3$ day (Wallace, $1958 \mathrm{~b}, 1958 \mathrm{c}$ ). It is however known that larvae remain in the vicinity of roots when they once have made contact (Wallace, 1958a). As a consequence they aggregate around roots after a few days (Kerstan and Röpke, 1977). To mimic aggregation, the average residence time of larvae in the upper $5 \mathrm{~cm}$ of soil (TOPLAR) is set at one day 
(for $2<\mathrm{pF}<2.7$ ). This upper $5 \mathrm{~cm}$ contains the roots in the experiment. Mortality of second stage larvae during migration is neglected because Golden and Shafer (1960) found more than $90 \%$ survival during 50 days.

Penetration into the root. The average time needed for penetration is 2 days at favourable $\mathrm{pF}$ and the penetration success has a fixed value of $30 \%$ (Johnson and Viglierchio, 1969; Shepherd and Wallace, 1959). This is only a rough estimate. Values up to $65 \%$ have been found in sugarbeet (Johnson and Viglierchio, 1969; Bridgeman and Kerry, 1980) and even 90\% in turnip rape, Brassica rapa L. var. oleifera Metzger (Kerstan, 1978). It has further been found that the penetration chance is highest when low numbers of larvae are added to roots (Johnson and Viglierchio, 1969; Kerstan, 1978; Bridgeman and Kerry, 1980), when the larvae are brought close to the roots (Kerstan, 1978), and when the earliest emerging larvae are used (Johnson and Viglierchio, 1969). These effects could not be included in this simple model because it is not clear which underlying principles determine the penetration success.

The model is written in CSMP. It uses the rectilinear integration method of Euler and a time step of integration of 0.05 day.

\section{Experimental materials and methods}

The model predictions were tested against the results of an experiment carried out in the spring of 1983. Batches of 30 cysts were introduced at depths of $61 / 2,8,11,17$ and $29 \mathrm{~cm}$ into PVC-cylinders (diameter $10 \mathrm{~cm}$ and length $32 \mathrm{~cm}$ ), filled with sandy loam and buried outdoors in heavy clay-soil. Four-week-old sugarbeet seedlings cv. Monohil were planted 3 days later (17 May, 1983), one in each cylinder, except in the control series. The seedlings were replaced with fresh seedlings at intervals of 10 days. The cysts were mixed in sandy loam-soil and packed in nylon gauze of $50 \mu \mathrm{m}$ mesh width. In this way the cysts could be recovered to count the remaining eggs and larvae. The root systems of the seedlings were also packed in $50 \mu \mathrm{m}$ mesh nylon gauze to limit root growth to the upper $5 \mathrm{~cm}$ of soil. The distances between the cysts and the root systems were $1 \frac{1}{2}, 3,6,12$, and $24 \mathrm{~cm}$. For each depth six cylinders were used. After staining the root system in hot lactophenol/cottonblue, the larvae wich had penetrated into the roots were counted. The first two countings were made in situ and the other three in a suspension of macerated root tissue in water (modified after Marks and McKenna, 1981). In this suspension the deep blue nematodes could be readily distinguished from the unstained root fragments. In six cylinders soil temperature and moisture content were measured daily. The temperature was recorded with maximum-minimum thermometers at 5,15 and $30 \mathrm{~cm}$ depth. The moisture content of soil samples, taken at depths of $0-5,5-10,10-15,15-20,20-25$ and $25-30 \mathrm{~cm}$, was determined gravimetrically. The model uses the dayly temperature and moisture recordings at different depths for the calculation of the rates of egghatch, emergence, migration and penetration.

\section{Experimental results}

At the end of the experiment, 50 days after the first planting on 17 May, between 36 and $49 \%$ of the eggs had hatched in the planted cylinders and $29 \%$ in the unplanted cylinders (average values of six cylinders). There were no significant differences for $\%$ 
Table 1. Statistical parameters of the penetration of Heterodera schachtii larvae into the roots of sugarbeet seedlings. Cysts of the bett cyst eelworm were inoculated at distances of $1.5,3,6$, 12 or $24 \mathrm{~cm}$ underneath sugarbeet seedlings in PVC-cylinders, filled with sandy loam and buried outdoors. The larvae penetrating were counted at intervals of 10 days between 17 May and 6 July 1983.

\begin{tabular}{llllll}
\hline Day & $\begin{array}{l}\text { Weight } \\
\text { of the root } \\
\text { system }(\mathrm{mg})\end{array}$ & $\begin{array}{l}\text { Number of } \\
\text { nematodes } \\
\text { penetrating }\end{array}$ & C.V. $(\%)^{a}$ & $\mathrm{r}^{2 b}$ & $\mathrm{p}^{c}$ \\
$0-10$ & 23 & 18 & 60 &. & \\
$11-20$ & 128 & 88 & 127 & 0.19 & 0.01 \\
$21-30$ & 337 & 103 & 68 & 0.15 & 0.02 \\
$31-40$ & 167 & 39 & 124 & 0.03 & 0.005 \\
$41-50$ & 418 & 42 & 66 & 0.11 & 0.005 \\
\hline
\end{tabular}

${ }^{a}$ Coefficient of variation of the number of nematodes penetrating.

${ }^{b}$ Squared correlation coefficient between the number of nematodes penetrating and the weight of the root system (fraction of the variance explained).

${ }^{c}$ Significance of the effect of the inoculation depth on the number of nematodes penetrating.

hatch between inoculation depths or between planted and unplanted cylinders. The absence of significant differences may be due to the high variability in egghatch (C.V. $=19 \%)$, which reflects the variation in inoculum (4970 \pm 860 eggs and larvae, C.V. $=17 \%)$.

The percentage of hatched eelworms penetrating was $22,21,13,12$ and 4 for the respective inoculation distances of $1 \frac{1}{2}, 3,6,12$ and $24 \mathrm{~cm}$. Although the number of nematodes penetrating was very variable (the coefficients of variations, $100 * \sigma / \mu$ amount to 66-127\%), the effect of the inoculation distance on penetration in the first four periods was significant ( $\mathrm{p}$-values of 0.005 to 0.02 , Table 1 ). There was a negligible effect of the weight of the root system on the number of nematodes penetrating (Table 1). Most nematodes penetrated 10-30 days after inoculation. In this period the soil temperature rose above $15^{\circ} \mathrm{C}$, after the cold and rainy first period of ten days (Fig. 3).

\section{Model results}

The model results correspond rather well with these experimental results. Simulated egghatch was $36 \%$ in the absence and between 39 and $48 \%$ in the presence of roots (respectively $29 \%$ and $36-49 \%$ in the experiment). The course of penetration is also much alike for the experiment and the simulation (Fig. 4). This simple model gives therefore a fair over-all description of the behaviour of $H$. schachtii in this experiment.

Differences appear if the numbers of nematodes penetrating are compared for each period of 10 days separately (Fig. 5). Only $57 \%$ of the variation in the number of penetrated nematodes is explained by the model, but the slope of the regression line (drawn black) deviates not significantly $(p>0.05)$ from 1 , the slope of ideal line $y$ $=\mathrm{x}$ (hatched). Evidently the model gives poor predictions over such short periods as 10 days, but there is no significant difference between simulation and experiment. 

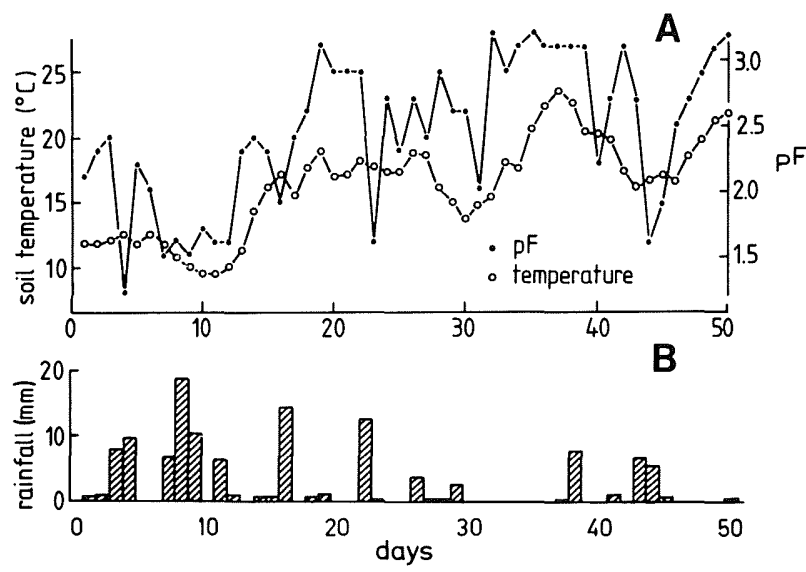

Fig. 3. Course of the soil temperature at $15 \mathrm{~cm}$ depth, the pF between 5 and $10 \mathrm{~cm}$ depth (A) and the rainfall (B) in the field experiment. Day $0=17$ May 1983.
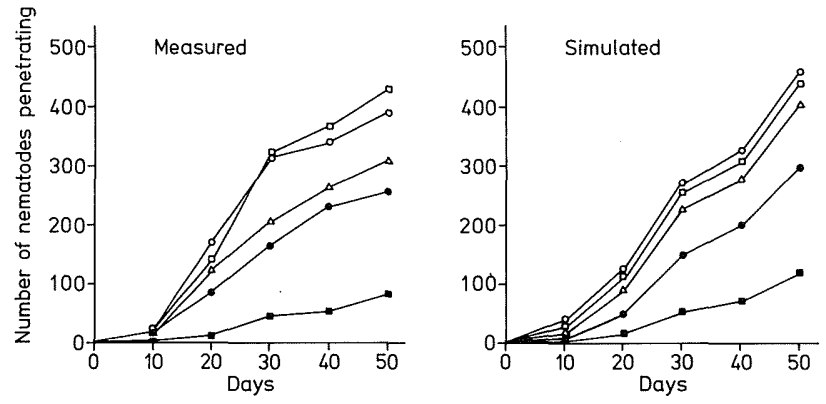

Fig. 4. Measured and simulated course of penetration into roots by Heterodera schachtii larvae, starting on 17 May 1983. Thirty cysts, containing 4970 eggs and larvae, were applied at distances of $1 \frac{1}{2}(\bigcirc 3(\square), 6(\Delta), 12(\bullet)$ and $24(\mathbf{D}) \mathrm{cm}$ from the roots.

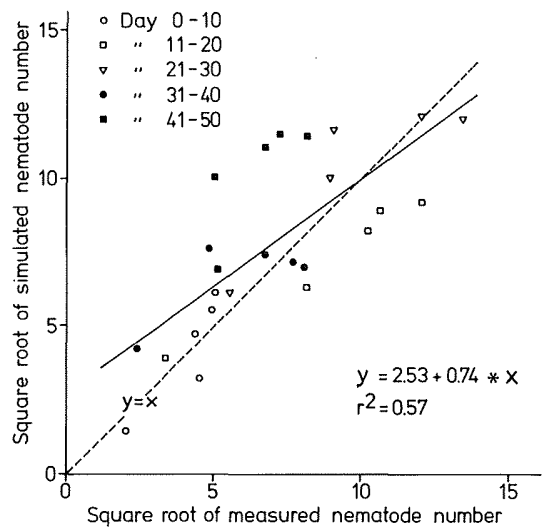

38
Fig. 5. Comparison of the real number of Heterodera schachtii larvae, penetrating into roots during 50 days, and the simulated number. $\mathrm{r}^{2}=$ 0.79 if the fifth period is excluded.

Neth. J. Pl. Path. 92 (1986) 
These short-term deviations are probably not so important if the model is used as a part of a whole season model, as the overestimation in one period may be compensated in another. The kind of deviation gives, however, clues as to what could be their cause.

\section{Discussion}

The experiment shows that $H$. schachtii larvae cover the same distances from the cyst to host roots as potato cyst nematodes (Rode, 1962). From cysts at a distance of 24 $\mathrm{cm}$, still $4 \%$ of the hatched larvae can penetrate the roots. The migration rate of about $10 \mathrm{~cm} /$ day under optimal conditions (Wallace, 1958b, 1958c) is greater than the rate at which sugarbeet roots grow downwards, namely $1-2 \mathrm{~cm} /$ day. Therefore migration should not be neglected in a description of the life cycle of cyst-nematodes.

Simulation models can be used to bridge the gap between detailed laboratory experiments and 'fields studies'. In this model three different effects on egghatch, measured in the laboratory, are combined, namely the effect of temperature (Maas and Heybroek, 1982), the effect of soil moisture, which influences emergence and hence the oxygen concentration within the cyst (Wallace, 1959) and the effect of leachates (Maas and Heybroek, 1982). The transport in the soil of leachates by draining rain water and its breakdown (Fenwick, 1956) are also taken into account. The model simulates egghatch rather well and this indicates that the conceptualisation of the system is correct. If only one of the factors would be omitted egghatch would be severely under- or overestimated.

The overall simulation of the penetration into the root compares well with the experiment (Fig. 4). Fig. 5 shows, however, that on some points the correspondence between the model and the experiment is not so good. Especially in the fifth period there is a big difference; the model gives an overestimation of more than $100 \%$. If this period would be omitted, the correlation coefficient in Fig. 5 would be $0.89\left(\mathrm{r}^{2}=0.79\right)$ and the regression line $(y=1.53+0.78 \mathrm{x})$ would be closer to the ideal hatched line. In the second period there is an underestimation of about $30 \%$. For the other three periods there is a rather good agreement between the model outcomes and the experimental results.

The underestimation in the second period and the overestimation in the fifth indicate that the model might be improved if the penetration success would not be fixed, but would depend on the circumstances and on the vitality of the larvae. Johnson and Viglierchio (1969) found that the first emerging larvae of $H$. schachtii had a higher penetration chance $(60 \%)$ than those emerging only five days later $(30 \%)$. Most larvae penetrating in the fifth period have emerged more than 5 days after the onset of egghatch and might therefore have a lower chance of penetration than $30 \%$. In addition, some of the larvae, penetrating in the fifth period, have (according to the model) been migrating in the soil for one or two weeks. Meanwhile their body reserves could be depleted and their penetration chance diminished, as Van Gundy et al. (1967) found for Meloidogyne javanica. The penetration chance of this nematode dropped with $50 \%$ in four days. Simulating the vitality of the larvae and making the penetration chance a function of vitality can probably improve the model, and will surely complicate it, but more experimental data are needed to justify this approach.

Another possible weakness of the model is the neglect of mortality of second stage

Neth. J. Pl. Path. 92 (1986) 
larvae. Mortality is ignored because Golden and Shafer (1960) found only negligible mortality of $H$. schachtii larvae in tap water or soil without roots, Van Gundy et al. (1967) found, however, for Meloidogyne javanica a quicker loss of body contents in soil with roots than in soil without roots or in tap water, because the larvae were more active in soil with roots. The loss of body contents was associated with higher mortality. Therefore mortality of $H$. schachtii larvae in soil with roots might not be negligible. If this is true the model would give somewhat lower predictions, especially if the larvae have to cover long distances from the cyst to the root.

This preliminary model of a part of the life cycle of $H$. schachtii gives reasonable predictions, indicating that the structure and most parameters of the model are probably correct. The weakest point in the model is probably the simulation of the penetration success, and this deserves further experimental studies. Other parts of the model which deserve attention, are the (lack of) mortality of second stage larvae and their direction of movement in the soil. That no mention is made in the literature of significant mortality or directed movement to roots may mean two things: 1) there is no mortality or directed movement, or 2) the experiments were not suitable to find mortality or directed movement. This model will be extended to cover the whole life cycle of $H$. schachtii together with the growth of sugarbeet.

\section{Acknowledgements}

The experiments were done at the Department of Nematology of the Agricultural University, Wageningen under the guidance of J.J. s'Jacob. The Department of Meteorology recorded rainfall. We thank J.E.J. Verhaaf for practical help and D. Peters, Mrs H.H. van Laar and A.F. van der Wal for comments on the manuscript.

\section{Samenvatting}

De voorjaarspenetratie van Heterodera schachtii in suikerbieten; een simulatieonderzoek

Volgens de toestandsvariabele-benadering werd een simulatiemodel ontwikkeld van de voorjaarspenetratie van het bietecystenaaltje. Het model beschrijft aan de hand van literatuurgegevens het uitkomen van de eieren, het verlaten van de cyst door de larven, de migratie naar en de penetratie in de wortel.

In 1983 werd een veldproef uitgevoerd om het model te toetsen. Cysten van $H$. schachtii werden op 5 dieptes tussen 6 en $29 \mathrm{~cm}$ ingegraven in PVC-cylinders, welke waren verzonken in de bodem. De bewortelingsdiepte van de suikerbiete-zaailingen die hierin groeiden werd beperkt tot $5 \mathrm{~cm}$ door nylon gaas van $50 \mu \mathrm{m}$ maaswijdte. Elke 10 dagen werden de larven geteld die in de wortels van deze plantjes waren gepenetreerd. Na 50 dagen was $40 \%$ van de eieren uitgekomen. Meer dan $20 \%$ van de gelokte larven penetreerden als de cysten ondiep waren ingegraven, en slechts $4 \%$ als de cysten op $29 \mathrm{~cm}$ diepte waren ingegraven.

Gedurende de eerste 40 dagen werd het verloop van de penetratie in de wortel met redelijke nauwkeurigheid door het model voorspeld $\left(\mathrm{r}^{2}=0.79\right)$. In de 5e periode van 10 dagen maakte het model echter een overschatting van meer dan $100 \%$. Het uitkomen van de eieren werd correct gesimuleerd. De verschillen in penetratie tussen 
het model en de proef zouden het gevolg kunnen zijn van een oververeenvoudigde simulatie van het penetratiesucces of van het verwaarlozen van de mortaliteit van de migrerende larven. Betere gegevens hierover zullen moeten komen uit detailproeven.

\section{References}

Bergman, B.H.H. \& Duuren, A.J. van, 1959. Het bietecystenaaltje en zijn bestrijding. VI. De invloed van wortels van waardplanten en excreten hiervan op de bewegingsrichting van larven van Heterodera schachtii in vitro. Mededelingen van het Instituut voor Rationele Suikerproductie. Bergen op Zoom, the Netherlands 29: 1-23.

Bridgeman, M.R. \& Kerry, B.R., 1980. The sex-ratio of cyst-nematodes produced by adding single second-stage juveniles to host roots. Nematologica 26: 209-213.

Fenwick, D.W., 1956. The breakdown of potato-root diffusate in soil. Nematologica 1: 290-302.

Golden, A.M. \& Shafer, T., 1960. Survival of emerged larvae of the sugar beet nematode (Heterodera schachtii) in water and in soil. Nematologica 5: 32-36.

Johnson, R.N. \& Viglierchio, D.R., 1969. Sugarbeet nematode (Heterodera schachtii) reared on axenic Beta vulgaris root explants. I. Selected environmental factors affecting penetration. Nematologica 15: 129-143.

Kerstan, U., 1978. Wirkung von Nematiziden auf die Wirt-Parasit-Beziehungen von Phytonematoden. I. Nachweis von Migrations- und Invasionsstörungen bei Heterodera schachtii mit der Glasstreifenmethode. 4. Vortragstagung zu aktuellen Problemen der Phytonematologie, Rostock, 8.6.1978: 46-61.

Kerstan, U. \& Röpke, S., 1977. Einfluss von Systemnematiciden auf das Verteilungsmuster der Larven von Heterodera schachtii im Wirtswurzelbereich. 3. Vortragstagung zu aktuellen Problemen der Phytonematologie, Rostock, 2.6.1977: 104-129.

Maas, P.W.Th. \& Heijbroek, W., 1982. Biology and pathogenicity of the yellow beet cyst nematode, a host race of Heterodera trifolii on sugar beet in the Netherlands. Nematologica 28: 77-93.

Marks, R.J. \& McKenna, L.A., 1981. A simple procedure for the efficient estimation of potato cyst nematode larvae in lactophenol treated roots. Ann. appl. Biol. 97: 323-324.

Rode, H., 1962. Untersuchungen über das Wandervermögen von Larven des Kartoffelnematoden (Heterodera rostochiensis Woll.) in Modellversuchen mit verschiedenen Bodenarten. Nematologica 7: 74-82.

Shepherd, A.M. \& Wallace, H.R., 1959. A comparison of the rates of emergence and invasion of beet eelworm Heterodera schachtii Schmidt and pea-root eelworm Heterodera göttingiana Liebscher. Nematologica 4: 227-235.

Van Gundy, S.D., Bird, A.F. \& Wallace, H.R., 1967. Ageing and starvation in larvae of Meloidogyne javanica and Tylenchulus semipenetrans. Phytopathology 57: 559-571.

Wallace, H.R., 1955. Factors influencing the emergence of larvae from cysts of the beet eelworm Heterodera schachtii Schmidt. J. Helminthology 29: 3-16

Wallace, H.R., 1956. Soil aeration and the emergence of larvae from cysts of the beet eelworm Heterodera schachtii Schm. Ann. appl. Biol. 44: 57-66.

Wallace, H.R., 1958a. Observations on the emergence from cysts and the orientation of larvae of three species of the genus Heterodera in the presence of host plants roots. Nematologica 3: 236-243.

Wallace, H.R., 1958b. Movement of eelworms. I. The influence of pore size and moisture content of the soil on the migration of larvae of the beet eelworm, Heterodera schachtii Schmidt. Ann. appl. Biol. 46: 74-85.

Wallace, H.R., 1958c. Movement of eelworms. II. A comparitive study of the movement in soil of Heterodera schachtii Schmidt and of Ditylenchus dipsaci (Kühn) Filipjev. Ann. appl. Biol. 46: 86-94.

Neth. J. Pl. Path. 92 (1986) 
Wallace, H.R., 1959. Further observations on some factors influencing the emergence of larvae from cysts of the beet eelworm Heterodera schachtii Schmidt. Nematologica 4: 245-252.

Wit, C.T. de \& Goudriaan J., 1978. Simulation of ecological processes. Pudoc, Wageningen, the Netherlands, 175 pp. 